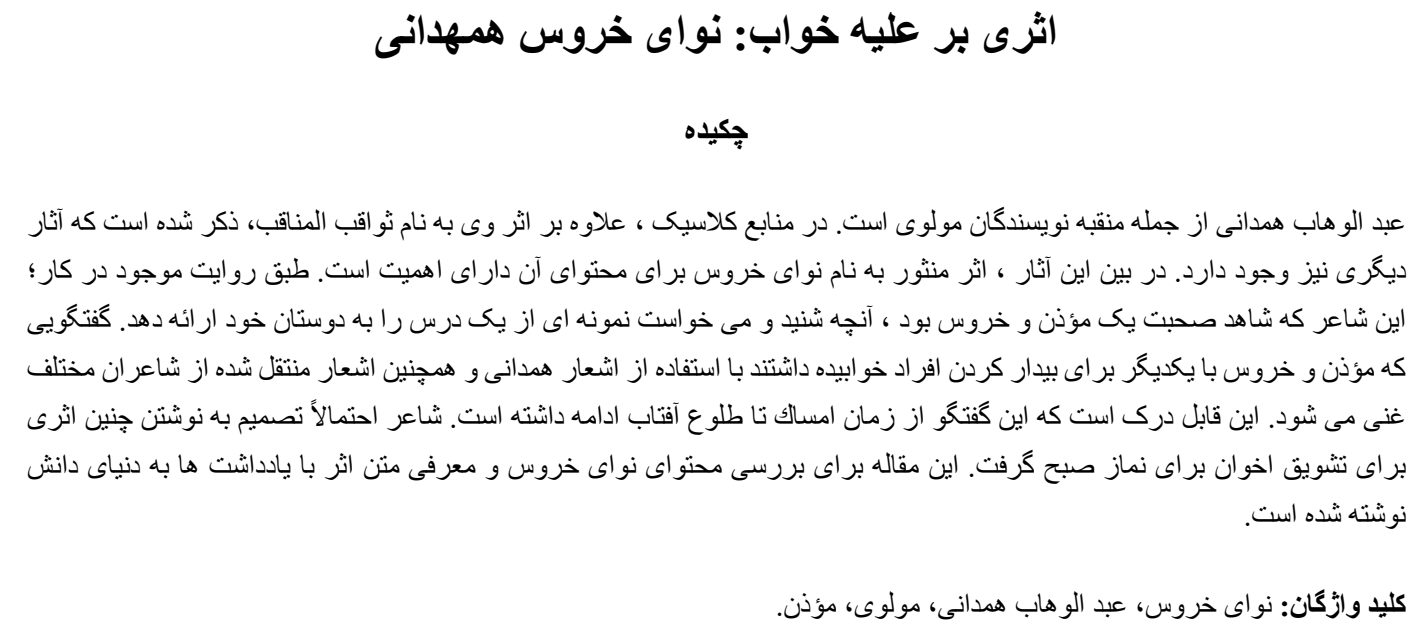

\title{
Uyku aleyhinde bir eser: Nevâ-yı Horûs-ı Hemedân̂̂
}

\section{Fatih ODUNKIRAN'}

APA: Odunkıran, F. (2020). Uyku aleyhinde bir eser: Nevâ-yı Horûs-ı Hemedânî. RumeliDE Dil ve Edebiyat Araştırmaları Dergisi, (20), 558-576. DOI: 10.29000/rumelide.792222.

\section{$\ddot{O} \mathbf{z}$}

Abdülvehhâb-ı Hemedânî, Mevlevî menkıbe yazarları arasında yer almaktadır. Klasik kaynaklarda, Sevâkıbu'l-menâkıb isimli eserinin haricinde başka eserlerinin de varlığından bahsedilmektedir. Bu eserler içerisinde Nevâ-yı Horûs isimli mensur eseri muhtevası itibariyle önemlidir. Eserde anlatıldığına göre; bir müezzin ve horozun konuştuğuna şahit olan şair, duyduklarını yazıya geçirerek dostlarına bir ibret örneği sunmak istemiştir. Müezzin ve horozun uyuyan insanları uyandırmak için birbirleriyle yaptıkları sohbet, Hemedânînin farklı şairlerden naklettiği manzumelerin yanı sıra kendi şiirlerini de kullanması ile eseri zenginleştirmiştir. Bu sohbetin imsak vaktinden güneş doğuncaya kadar sürdüğü anlaşılmaktadır. Şair muhtemelen ihvanı sabah namazına teşvik etmek için böyle bir eser yazmaya karar vermiştir. Bu makale Nevâ-yı Horûs'un muhtevasını incelemek ve eserin metnini notlarla beraber ilim âlemine tanıtmak için kaleme alınmıştır.

Anahtar kelimeler: Nevâ-yı Horûs, Abdülvehhâb-ı Hemedânî, Mevlevi, Müezzin

\section{A work against sleep: Nevâ-yı Horûs-ı Hemedânî}

\begin{abstract}
Abdülvehhâb-1 Hemedânî is among the menkabe authors of Mevlevî Order. In classical sources, besides his work named Sevâkıbu'l-menâkıb, it is mentioned that there are other works. Among these works, the prose work named Nevâ-yı Horûs is important for its content. According to the narration in the work; The poet, who witnessed the conversation of a muezzin and a rooster, wanted to present an example of a lesson to his friends by writing what he heard. The conversation that muezzin and the rooster had with each other to awaken the sleeping people enriched the work by using Hemedânî's
\end{abstract} [Makale kayıt tarihi: 05.08.2020-kabul tarihi: 31.08.2020; DOI: 10.29000/rumelide.792222] 
poems from different poets as well as his own poems. It is understood that this conversation continued from the time of dawn until the sunrise. The poet probably decided to write such a work to encourage the prayer to the morning prayer. This article was written to examine the content of Nevâyı Horûs and to present the text of the work with notes to the academic world.

Keywords: Nevâ-yı Horûs, Abdülvehhab el-Hemedani, Mewlewi, Muezzin

\section{مقدمه}

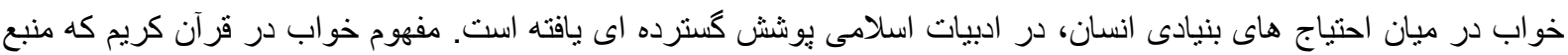

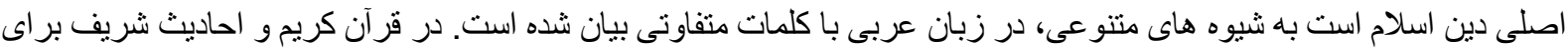

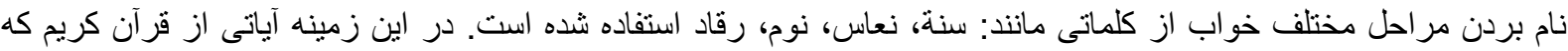

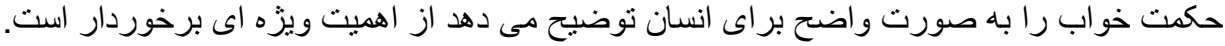

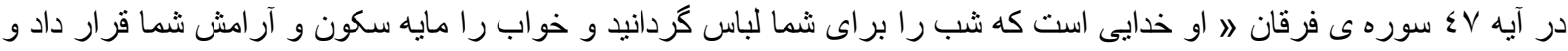

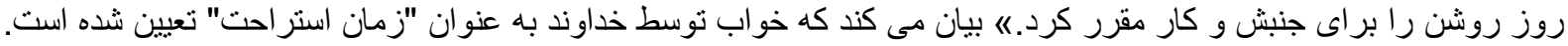

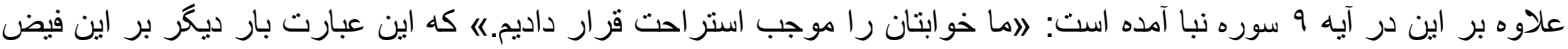

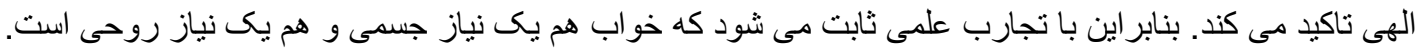

در حديث شريف هم با اشكال مختلفى موضو عاتى به خواب اختصاص داده شده است. اما در احاديث بيشتر از حكمت خواب، آداب

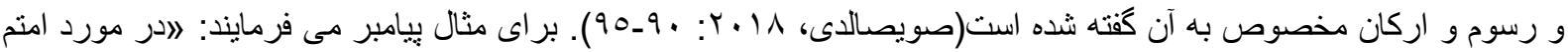

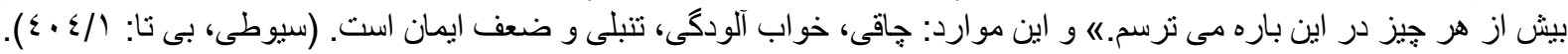

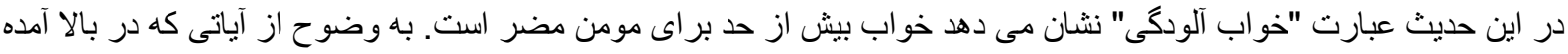

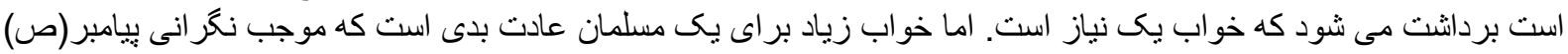

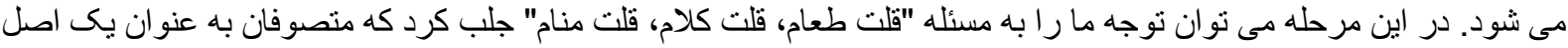

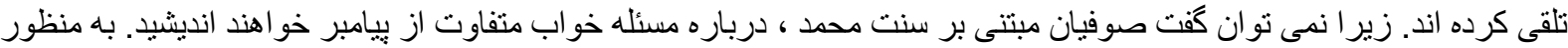

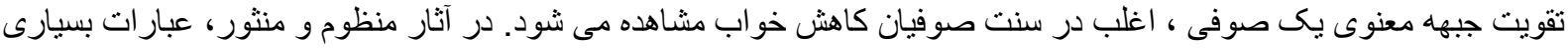

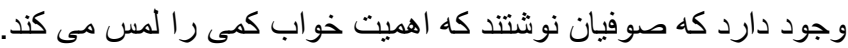

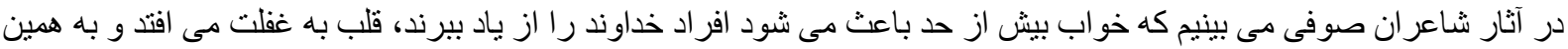

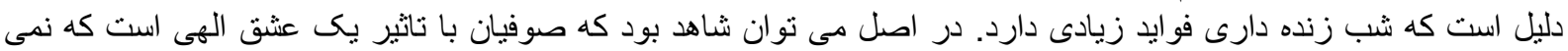

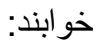

$$
\text { خواب شن شيد ديده من بر فلك استاره شمرد }
$$

$$
\text { خوابم خفتند و من دلثده را خواب نبرد ديده جنان رفت كه هركز نايد }
$$

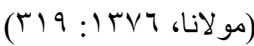

نادر است كه صوفيان شاعر آثار مستقل درباره خواب بنويسند.به همين دليل نواى خروس به عنوان اثرى كه بخوبى نشان مى دهد

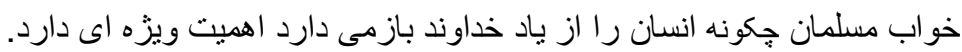

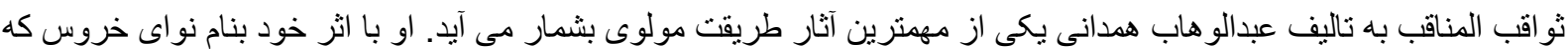

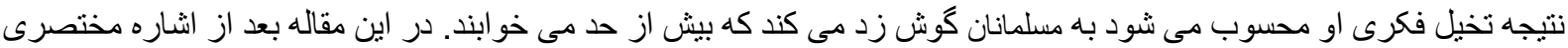

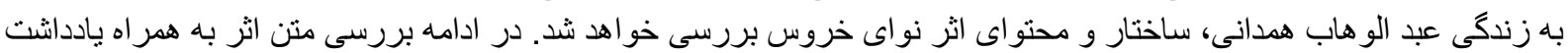

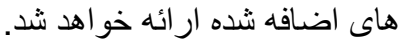




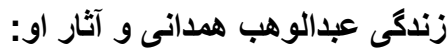

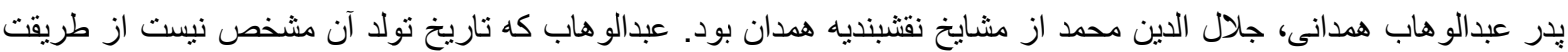

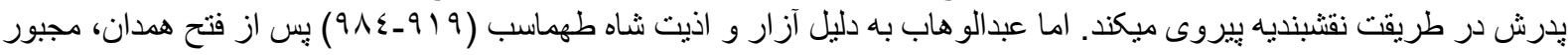

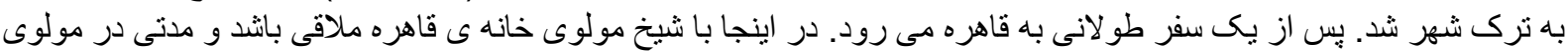

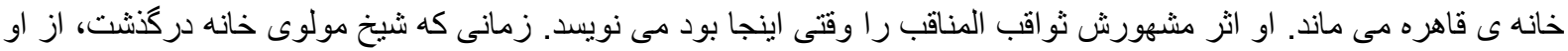

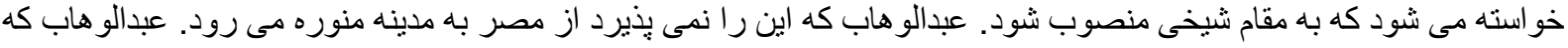

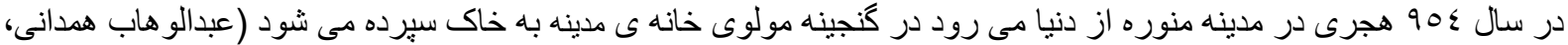

.) (1V-17:1rq.

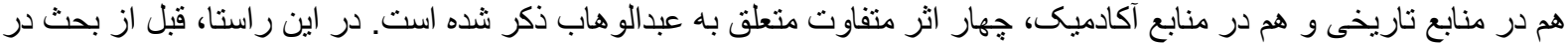

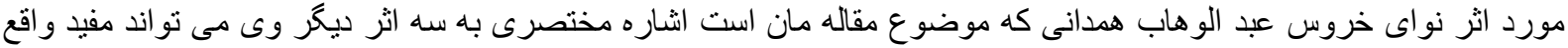

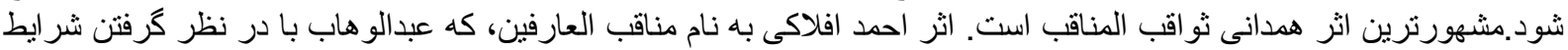

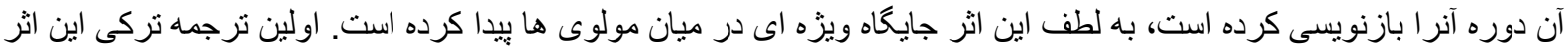

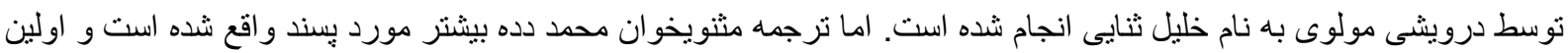

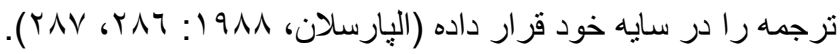

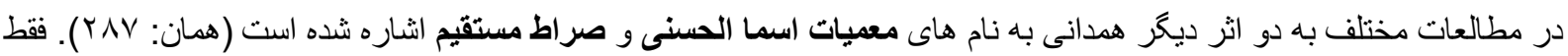

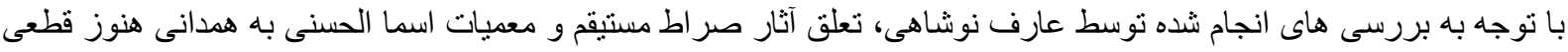

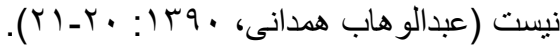

\section{نواى خروس:}

با توجه به بررسى هاى انجام شده توسط عارف نوشاهى، دو نسخه از نواى خروس، يكى در استانبول و وديكرى در مدينه بيدا شده

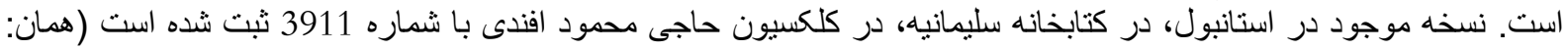

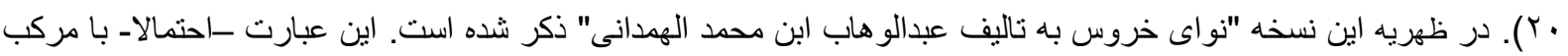

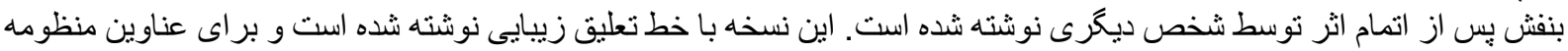
ها از مركب قرمز استفاده شده است.

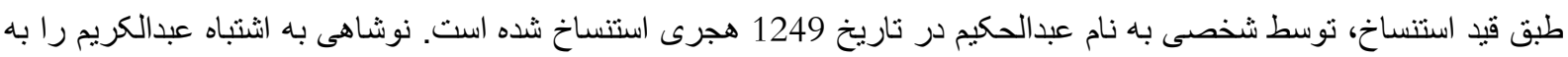

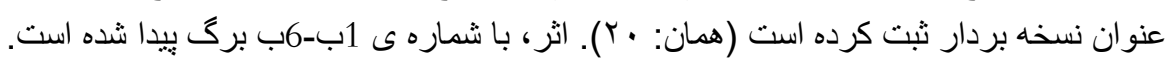

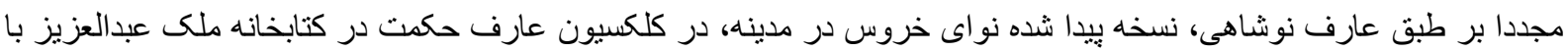

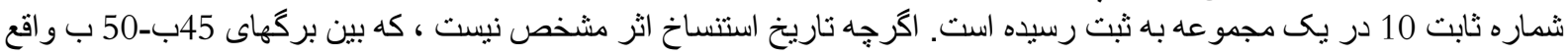

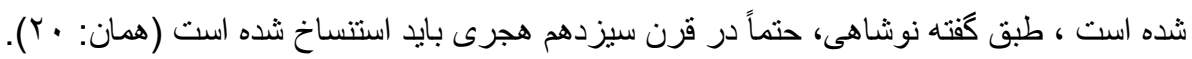

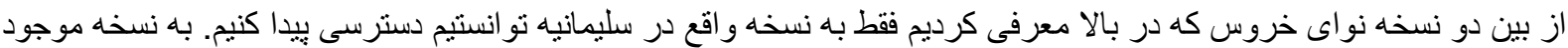

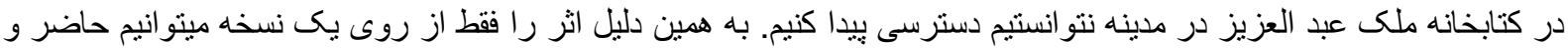

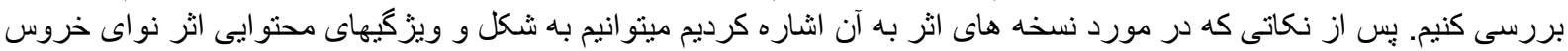
بيردازيم.

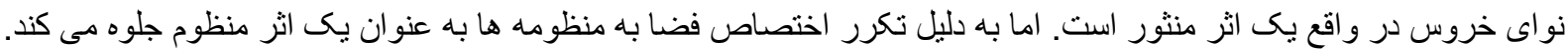

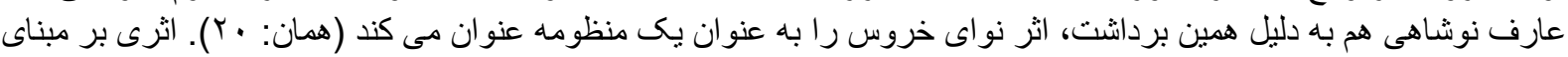

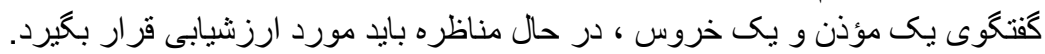




\section{مى توان اين كفتكو را كه همدانى در تخيل خود تصريح كرد ، خلاصه كرد:}

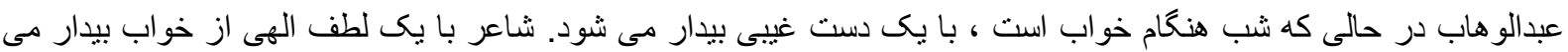

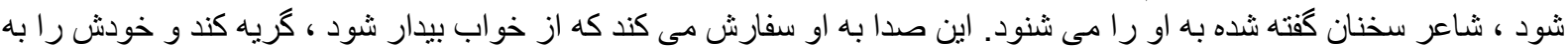

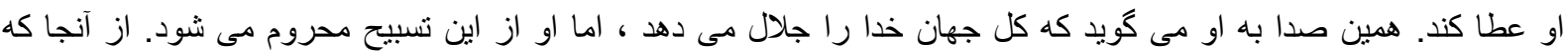

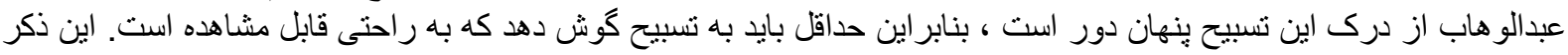

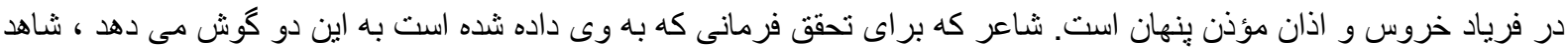

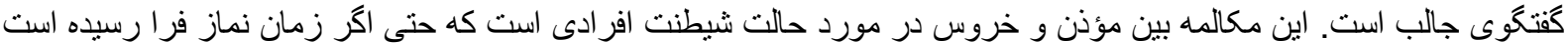

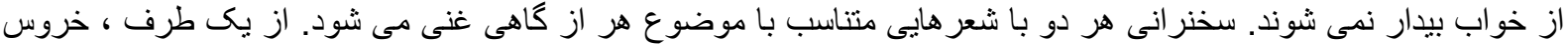

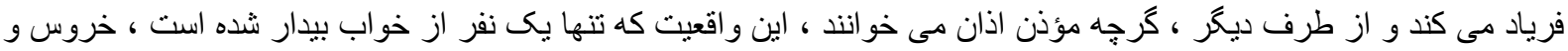

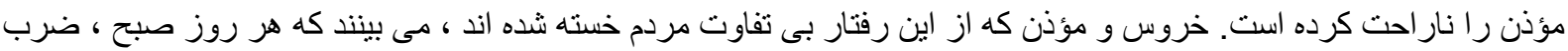

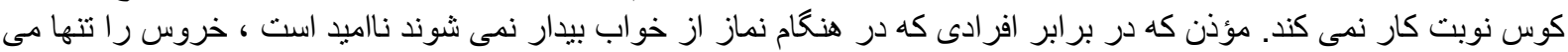

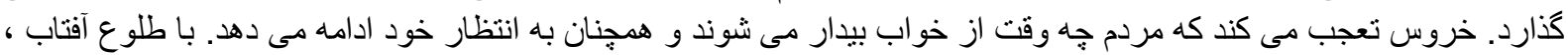

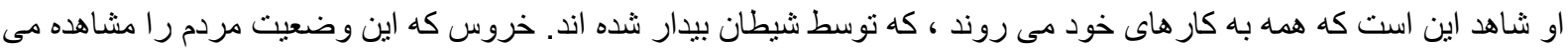

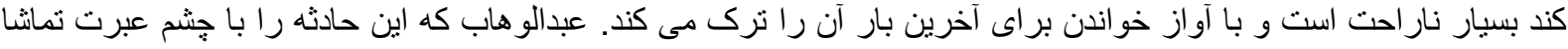

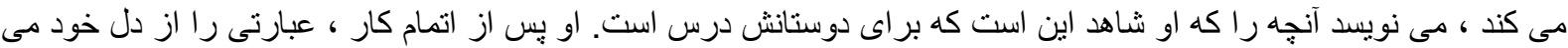

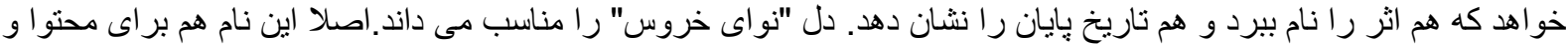

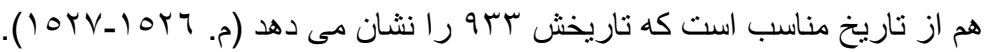

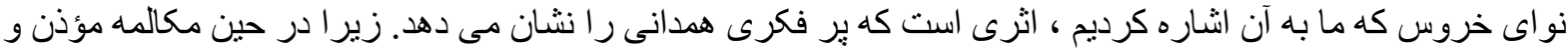

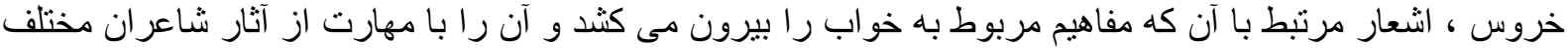

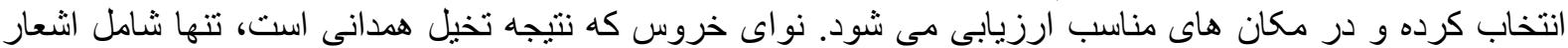

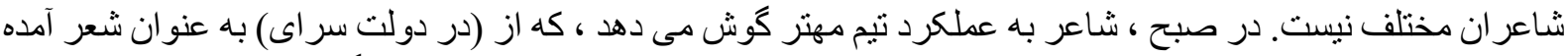

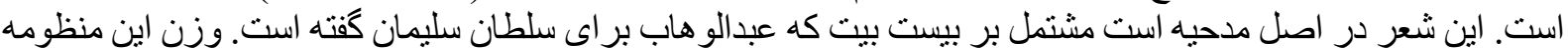

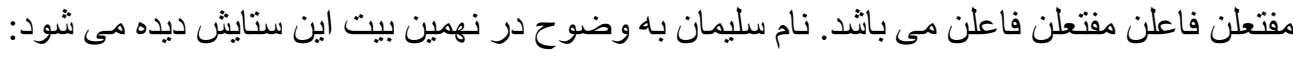

$$
\text { شاه سليمان كه بست ديو لعين و نثست خاتم دولت بدست بر سر تخت وصال }
$$

با اين حال ، اين ستايش شاعر قطعاً هيج انتظارى از منفعت ندارد. در واقع ، اين به وضوح بر اين موضوع در بيت مخلص وى تأكيد مى كند:

$$
\text { مدح تو وهابى از غيرت دين ميكند نى يى دنياى دون با طلب جاه و مال }
$$

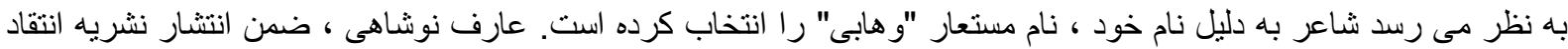

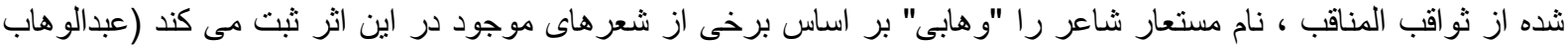

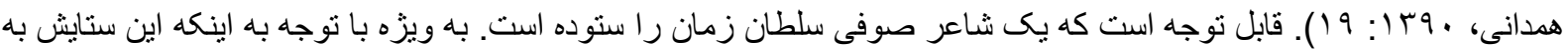

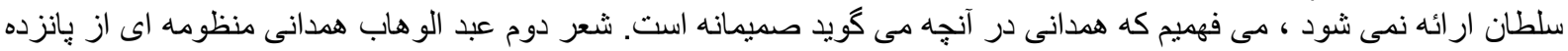

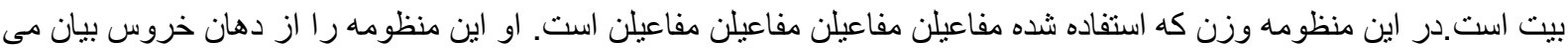

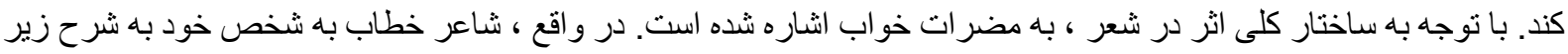

$$
\text { عجب حاليست وهابى كه خود بيوسته در خوابى ز مردم هر كرا يابى ز خو ابش ميشود مانع }
$$

منظومه سوم شاعر كه وزنش بر وزن اخرب است، يك رباعى است. در اين رباعى مى كويد كه خواب براى او بهتر از بيدار ماندن است:

بيدارئ ما كه غييتست و بهتان با ديدن محنت و جفاى دوران

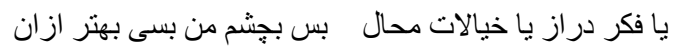




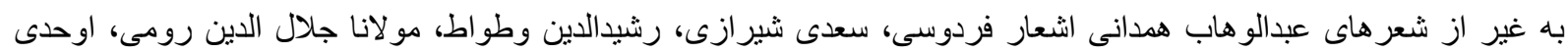

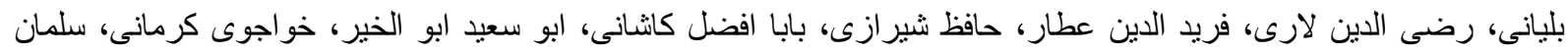

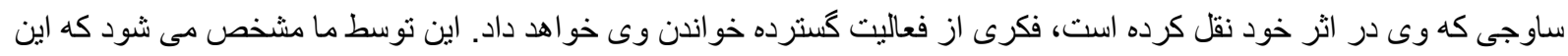

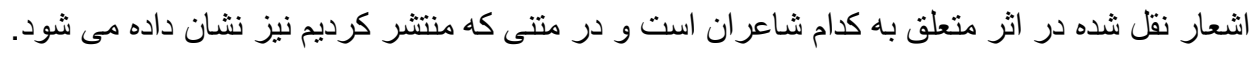




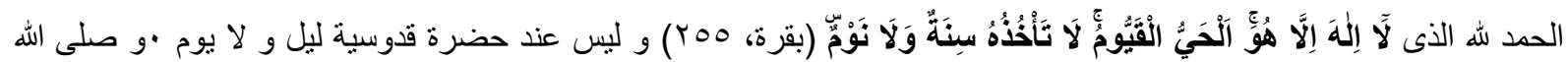

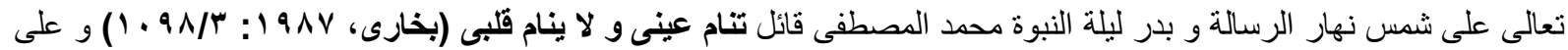

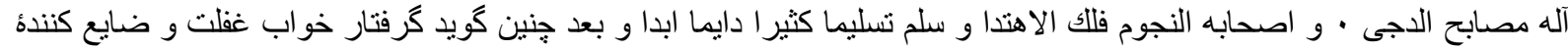

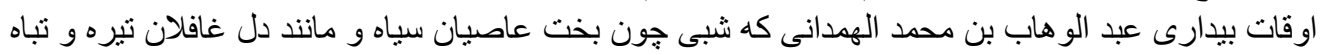

$$
\text { نه بهر ام بيدا نه كيو ان نه ماه }
$$

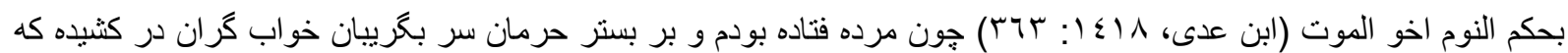

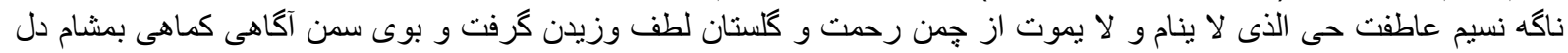

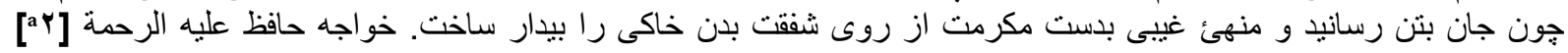

$$
\begin{aligned}
& \text { بيت } \\
& \text { سحرم دولت بيدار ببالين آمد } \\
& \text { كفت بر خيز كه آن خسرو شيرين آمد } \\
& \text { (حافظ، Vrr ( ) ( }
\end{aligned}
$$

و فرمود كه اي عمر عزيز بباد فساد داده جهه خفتَّ بر خيز

$$
\text { مصر كه در خواب غفلتى بر خيز }
$$

خواب جو اب دهو از آتش قهر قهار ببر هيز آبى از ديده بر روى كار خود آور و جبين نباز از روى عجز بر خاك مذلت ماليده از

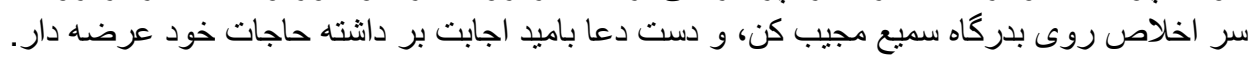

$$
\begin{aligned}
& \text { مصراع } \\
& \text { آخر كه زد اين در كه درش نكثودند } \\
& \text { (بابا افضل، بى تا: r • ( ) }
\end{aligned}
$$

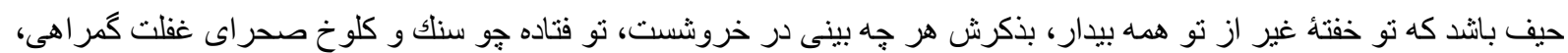

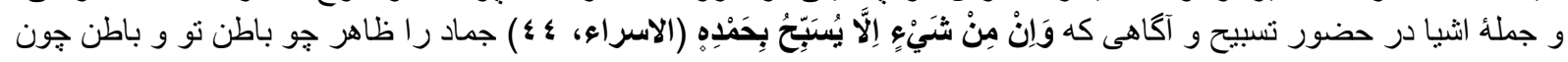
ظاهر نو.

$$
\begin{aligned}
& \text { مصراع } \\
& \text { با من و تو مرده با او زنده آيد }
\end{aligned}
$$

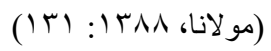

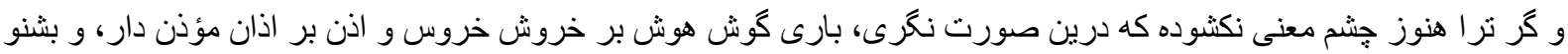

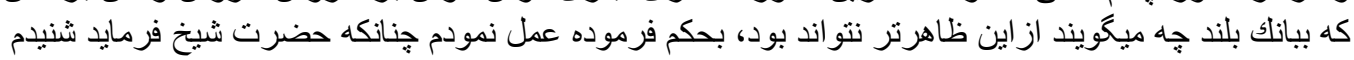




$$
\begin{aligned}
& \text { دوش مر غى بصبح مى ناليد } \\
& \text { عقل و صبرم ببرد و طاقت و هوش بالئ } \\
& \text { يكى از بندكان مخلص را } \\
& \text { مكر آواز من رسيد بكوش لنكان مليط } \\
& \text { كفت باور نداشتم كه ترا } \\
& \text { بانك مر غى جنين كند مدهوش بارش } \\
& \text { كفتمش شرط آدميت نيست } \\
& \text { مر غ تسبيح خوان و من خاموش }
\end{aligned}
$$

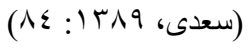

و مؤذن بر [ץ[] بالاى منار جون بلبل بيقرار كه از بهر داستان وصف كل و كلزار سرايد، در تقديس و تنزيه ملك فرد صمد، قبل از اذان صبح اين ابيات ميخواند

$$
\begin{aligned}
& \text { شعر } \\
& \text { سبحان خالقى كه صفاتش ز كبريا } \\
& \text { بر خاك عجز ميفكند عقل اصفيا } \\
& \text { كر صد هزار سال همه خلق كاينات } \\
& \text { فكرت كنند در صفت عزت خدا } \\
& \text { آخر بعجز معترف آيند كه اي اله } \\
& \text { دانسته شد كه هيج ندانسته ايم ما } \\
& \text { آنجا كه بحر نامتناهيست موج زن } \\
& \text { شايد كه شبنمى بكند قصد آثنا } \\
& \text { و آنجا كه كَش هوش بدردز بانك رعد } \\
& \text { زنبور و سبوى ترا جون كند ادا }
\end{aligned}
$$

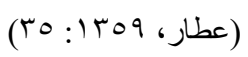

$$
\begin{aligned}
& \text { در جنب نور ذات بود ظلمت كدر } \\
& \text { البدر فى الطليعة و الثمس و الضحى ندر دات }
\end{aligned}
$$

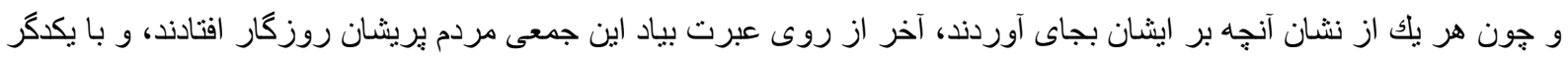

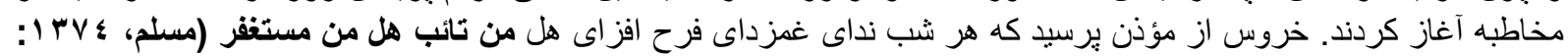

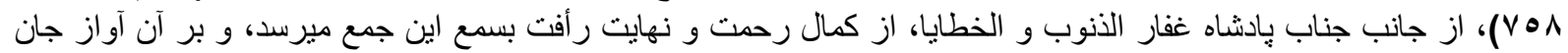

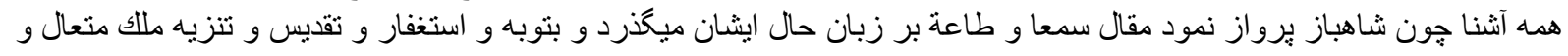




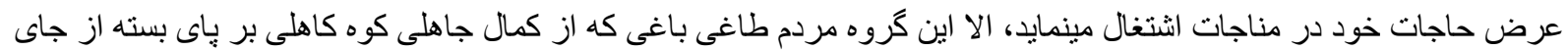

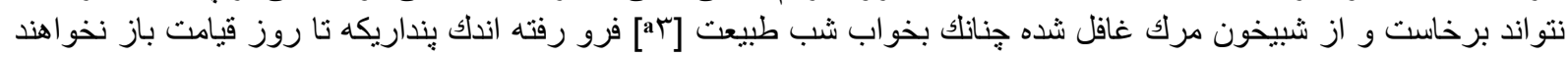

$$
\text { رهاد از مرك خود نمى آريم }
$$

شمهُ از شيمهُ اين قوم بيان فرماى تا تسلى كامل حاصل آيد مؤذن كه تواند بود كه آنجه برسيدى در حق اين طايفه باثد كه مشابه آن قومند و بمعنى مخالف جنانكه مو لانا ميفرمايد:

$$
\begin{aligned}
& \text { كريت بصورت آدمى انسان بدى }
\end{aligned}
$$

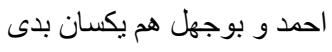

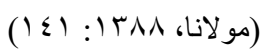

يكسر مو بر نن ايشان بى آكاهى و حضور نيست، بلكه از كمال استغراق ايثان را بدان آكاهى هم شعور نيست. هميثه غرق لجهُ وحدت و مدام مست مى احديت جنانكه خو اجه حافظ فرمايد:

$$
\begin{aligned}
& \text { بيت } \\
& \text { مستم كن آنجنان كه ندانم ز بيخودى }
\end{aligned}
$$

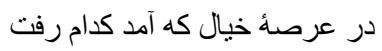

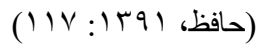

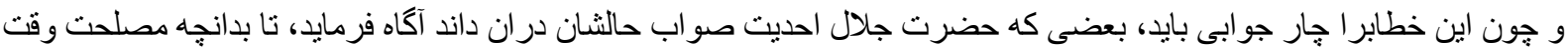
باثند اقدام نمايند و آنانكه جنان مستغرق بآبند هم خود بكرم عذر ايثان طلب نمايد البان حضرت مو لانا جامى عليه الرحمة فرمايد:

$$
\text { نو ديت در ميانه هيج نه هر جه هيت اوست }
$$

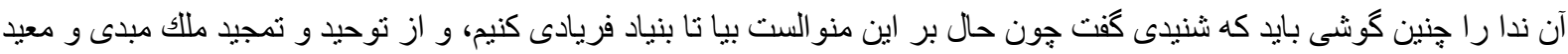

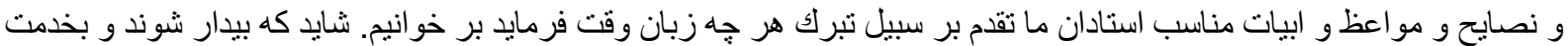

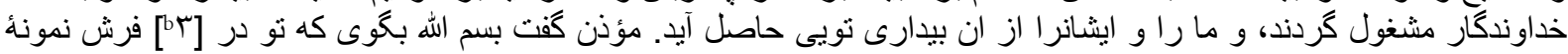

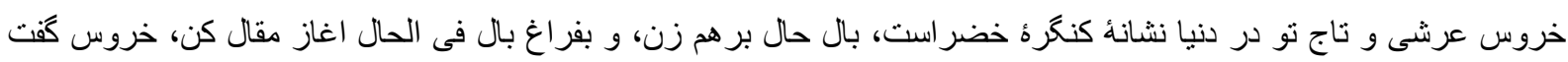

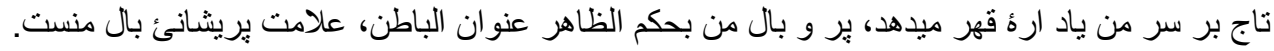

$$
\begin{aligned}
& \text { بيت } \\
& \text { فردا كه خروس عرش برواز كند } \\
& \text { معلوم شود كه ماكيانيم همه }
\end{aligned}
$$

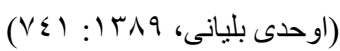

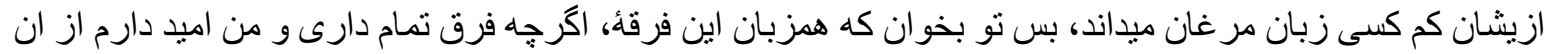

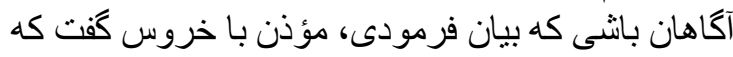




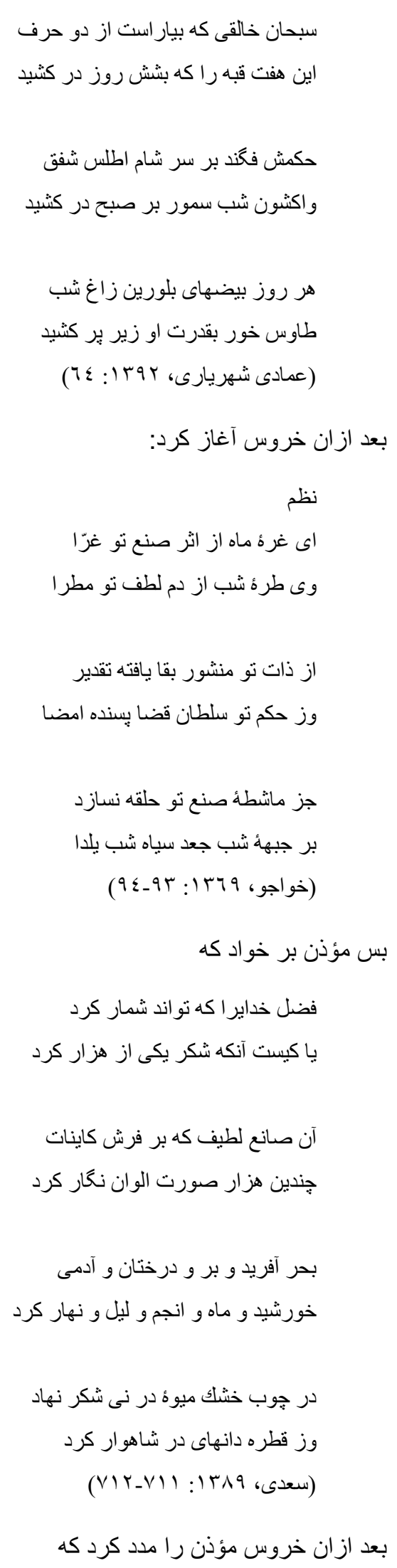




$$
\text { شعر كدام فضل بجاى آورد كسى }
$$

$$
\text { اي قطرة منى سر بيجاركى بنه }
$$$$
\text { ابليس را غرور منى خاكسار كرد }
$$

$$
\text { فير هيزكار باش كه دادار آسمان }
$$

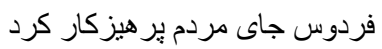

$$
\text { نابرده رنج كنج ميسر نميشود }
$$$$
\text { مزد آن كرفت جان بر ادار كه كاركرد }
$$$$
\text { هركس عمل نكرد و عنايت اميد داشت }
$$$$
\text { دانه نكثت ابله دخل اختيار كرد }
$$

$$
\text { همجنان باقئ ابيات را مؤذن نمام كرد كه }
$$

$$
\text { دنيا كه جسر آخرنش خو اند مصطفى }
$$$$
\text { جاى نشست نيست ببايد كذار كرد }
$$

دار القرار خانهُ جاويد آدميست

اين جاى رفتنست ببايد فرار كرد

$$
\text { بس استخو ان كه هاون دوران روزكار }
$$

خردش جنان بكوفت كه خاكث غبار كرد

$$
\text { ظالم نماند و قاعدة ظلم ازو بماند }
$$

$$
\begin{aligned}
& \text { سعدى جو هر نفسى كه بر آورد در سحر } \\
& \text { جون صبح در بسيط زمين انتشار كرد }
\end{aligned}
$$

(ه) (همان: (v)

باز خروس برواز آمد و بآواز بلند آغاز كرد كه

نظم

اى در هو اى معرفت قدرت جو باز

سيمرغ جشم و باز خرد جشّم دوخته 


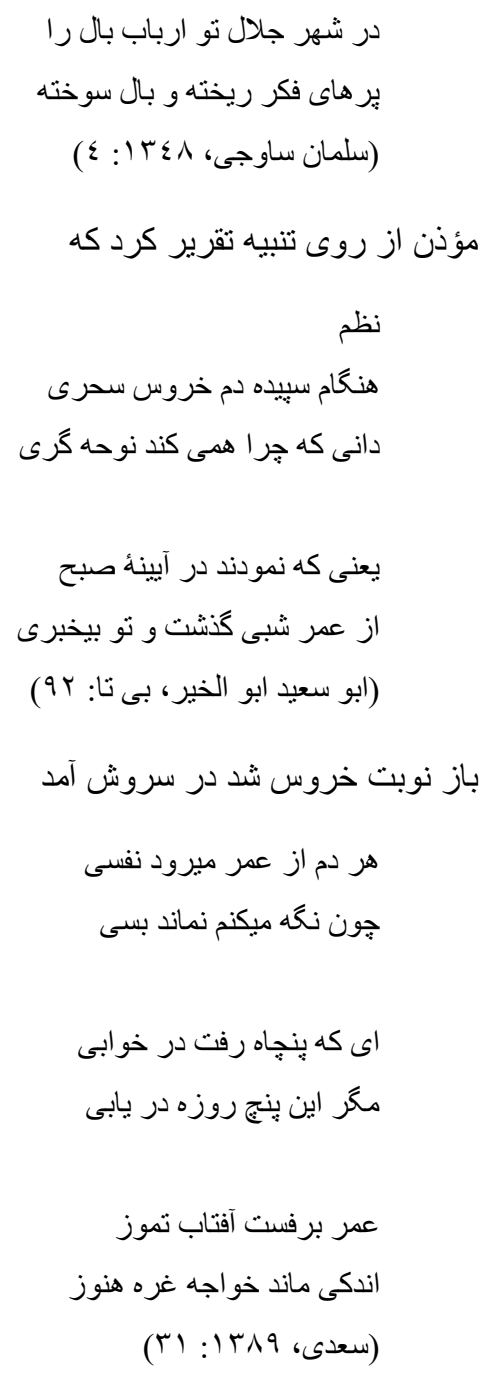

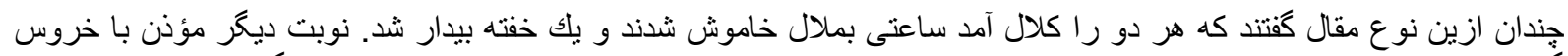

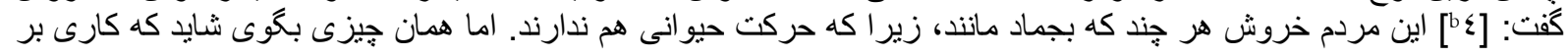
آيد خروس كفت بفرياد من ايثان ميكويند:

$$
\begin{aligned}
& \text { تا نشنوى ز مسجد اذينه بانك صبح } \\
& \text { يا از در سراى اتابك غريو كوس } \\
& \text { لب از لب جو جشم خروس ابلهى بود } \\
& \text { بر داشنن بكفتن بيهوده خروس }
\end{aligned}
$$$$
\text { (همان: (هر) }
$$

بس نو بكوى يا ساعتى صبر كن تا آواز كوس سلطان در كَش ايشان نشيند شايد كه بر خيزند. خروس و مؤذن دراين كفت و شنيد

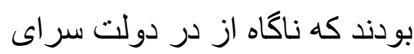




$$
\begin{aligned}
& \text { نظبح سعادت نو ال نير اوج جلال } \\
& \text { در بحار جمال درى برج كمال } \\
& \text { رافع اعلام علم فاتح ابو اب عدل } \\
& \text { كاسر اعناق جهل خافض ظلم ضلال } \\
& \text { بخت شب كفر شد تير در ايام او } \\
& \text { ز آيينهُ روز دين برد غبار وبال } \\
& \text { دولت بيدار او كرد بخواب عدم } \\
& \text { فتته شيخ ابن غال مفسد شيطان خصال } \\
& \text { قامت خود در عراق تا ننمود او نكفت } \\
& \text { راست مؤذن اذان بر نهج اعتدال } \\
& \text { كثت جو فاروق ازو دين محمد عيان } \\
& \text { باز بكردون رساند صوت اذان جون هلال } \\
& \text { شب نتو انست برد نام صحابه بروز } \\
& \text { سعى جميل ويش داد ز منبر جمال } \\
& \text { شمع شبستان دين ماه سما يقين } \\
& \text { مهر سيهز برين كيست بكو بى زوال } \\
& \text { شاه سليمان كه بست ديو لعين و نشست } \\
& \text { خاتم دولت بدست بر سر تخت وصال } \\
& \text { تاجو هما سايه كرد بر سر ما مرغ دل } \\
& \text { شام و سحر جون خروس گفت بلند اين مقال } \\
& \text { مسجد عالم كه هست سقف رفيعش سما } \\
& \text { فرش منيعش زمين قامتهايش جبال } \\
& \text { تا بودش مهر و مه با شهب لامعه } \\
& \text { مشعل و قنديل شمع در لمع و اشتعال }
\end{aligned}
$$




$$
\begin{aligned}
& \text { بايةٔ منبر بلند شِت جماعت قوى } \\
& \text { قامت محر اب خم بهر حق از ابتهال } \\
& \text { عز امام خطيب جمله ز نام تو باد }
\end{aligned}
$$

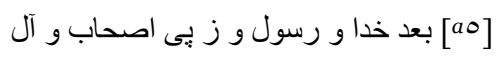

$$
\begin{aligned}
& \text { آنجه تو در راه دين كرده اى نازنين } \\
& \text { كس نشنيده ست اين صد يكش از يور زال } \\
& \text { وقت طلوع نبى لجه ساده ماند } \\
& \text {... دى انر ا كنون از تو نمايم مثنال } \\
& \text { لجهُ كفر عراق تيغ تو يكدم كثيد } \\
& \text { كرد بكردون رساند از تلك بحر نكال } \\
& \text { كثت برى ذمت تيغ تو از دين } \\
& \text { زانكه غزاى فرنك بود اهم اين قتال } \\
& \text { مدح نو وهابى از غيرت دين ميكند } \\
& \text { نى يى دنياى دون با طلب جاه و مال } \\
& \text { دنيى و اسباب او در نظر همتش } \\
& \text { خاشهُ افتاده در بحر محيطز لال }
\end{aligned}
$$

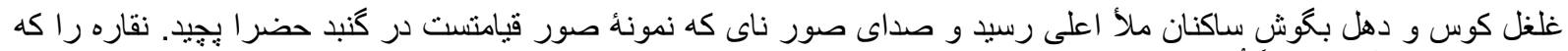

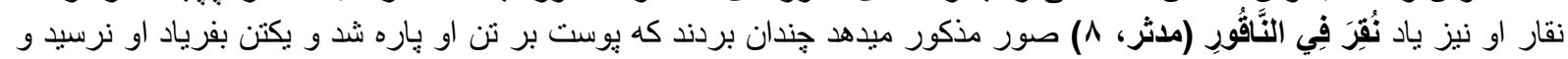

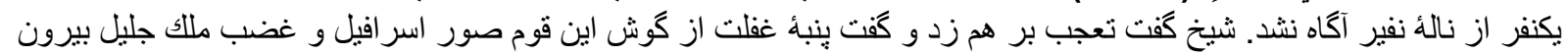

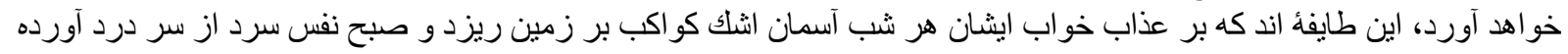

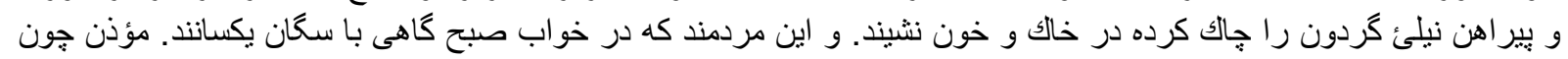

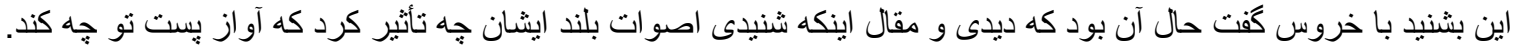

$$
\begin{aligned}
& \text { شب رفت و حديث ما بيايان نرسيد } \\
& \text { شب را جه كند حديث ما بود دراز } \\
& \text { (مولانا، }
\end{aligned}
$$

بيا تا برويم كه ايشان را آنكس كه در خواب كرده ست يعنى شيطان هم او بيدار خو اهد ساخت بهنغام طعام و كاه كناه خروس كفت

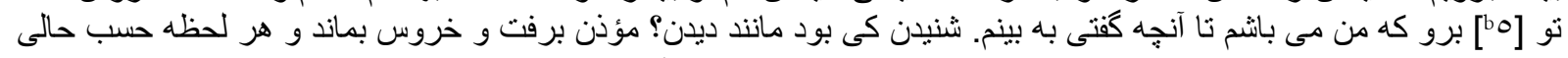

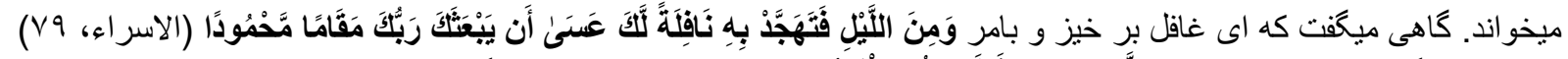

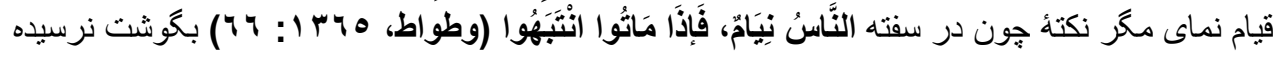




$$
\begin{aligned}
& \text { رباعى }
\end{aligned}
$$

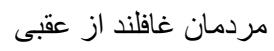

$$
\begin{aligned}
& \text { همه كَّيى بخفتحان مانند } \\
& \text { ضرر و غفلتى كه مى ورزند } \\
& \text { جون بميرند آنحهى دانند } \\
& \text { (هان: (77) } \\
& \text { و يا نشنيدة كه بزركان كفته اند } \\
& \text { نظم } \\
& \text { هر سحر بر خيز استغفار كن } \\
& \text { فرصنى اكنون كه دارى كار كن }
\end{aligned}
$$

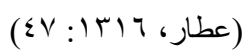

$$
\begin{aligned}
& \text { زنده دار از ذكر صبح و شام را } \\
& \text { در تغافل مكذر ان ايام را } \\
& \text { ( } \\
& \text { و زمانى بر زمان مير اند كه } \\
& \text { زد سحر طاير قدسم ز سر سدره صفير }
\end{aligned}
$$

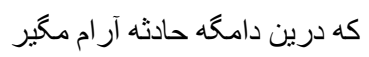

$$
\begin{aligned}
& \text { قدسيان بهر تو آر استه خلوتكه انس }
\end{aligned}
$$

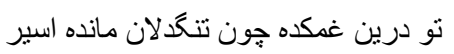

$$
\begin{aligned}
& \text { هيج جانيست كه عكس رخ او بيدا نيست } \\
& \text { جرم آيينه بود كر نبود عكس بذير }
\end{aligned}
$$

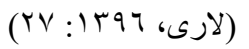

$$
\begin{aligned}
& \text { و دمى اين زمزمه ميزد كه } \\
& \text { رباعى } \\
& \text { يا رب دل پِاك و جان آكاهم ده } \\
& \text { آه شب و كريأ سحركاهم ده } \\
& \text { در راه خود اول ز خودم بيخود كن } \\
& \text { آنكه بيخود ز خود بخود ر راهم ده }
\end{aligned}
$$




$$
\begin{aligned}
& \text { اى نالله بِير خانقاه از غم تو } \\
& \text { افغان خروس صبحكاه از غم تو } \\
& \text { وى كريأ طفل بى كناه از غم تو } \\
& \text { آه از غمتو هزار آه از غمتو تو }
\end{aligned}
$$

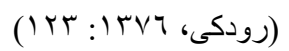

خروس بدين كونه شبى كذر انيد تا صبح صادق نيز باو متفق شد و بعضى از آن ابيات لايق كه مو افق وقت خو اندند اينست كه زبان قلم و هابى بيان آن ميكند:

نكردى كريه و زارى بنزد حضرت بارى مناجات از نو بارى مكن اين يكنفس ضايع

$$
\text { بعذر رفته اى نادان آهى كثى سوزان }
$$

بنزد حضرت يزدان رفيقان تاسحر كريان جكر سوزان دل بريان دمى ساجد دمى راكع لبرد

$$
\begin{aligned}
& \text { همه عمر خودى مضطر نو در صحر اى خواب خور }
\end{aligned}
$$

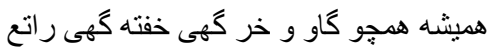

$$
\begin{aligned}
& \text { بكوى خلق يِيش و يّ كجا رفتند ای ناكس } \\
& \text { زمين خورد و نسازد بس همان نيست آنجنان جايع }
\end{aligned}
$$

$$
\begin{aligned}
& \text { نكردى هيج ایى ابله ز آواز خروس آكه } \\
& \text { نه از فرياد كوس شه نه بانك مسجد جامع } \\
& \text { ز عين جهل و بيعارى تر ازين خواب يندارى } \\
& \text { نخو اهد بود بيدارى قيامت كر شود و اقع } \\
& \text { تو خود خيزى بود بهتر كه آيد خسرو خاور } \\
& \text { كند بيدارت اي مضطر به تيغ شوكت قاطع }
\end{aligned}
$$




$$
\begin{aligned}
& \text { بساط شب نماند طى كريزد خيل خواب از وى } \\
& \text { بغرب و شرق يى در يَى حسام او شود لامع } \\
& \text { عجب حاليست و هابى كه خود يِيوسته در خوابى } \\
& \text { ز مردم هر كر ا يابى ز خو ابش ميشود مانع } \\
& \text { عمل در تو سر مويى نه بينم غير بر كويى }
\end{aligned}
$$

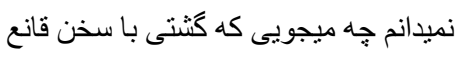

$$
\begin{aligned}
& \text { درين دركاه سبحانى جه بايد هيج ميدانى } \\
& \text { شكسته دل حزين جانى وزان بس ديدة دامع } \\
& \text { جو من نه اين و نه آنم بكار خويش حير انم }
\end{aligned}
$$

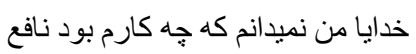

$$
\begin{aligned}
& \text { رضاى حضرتت يا رب بجه كارست و جه مشرب } \\
& \text { بر آنم دار روز و شب بحق سيد شافع }
\end{aligned}
$$

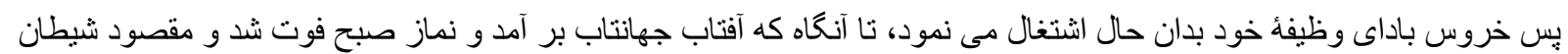

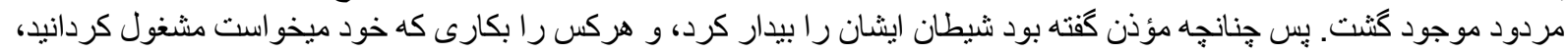

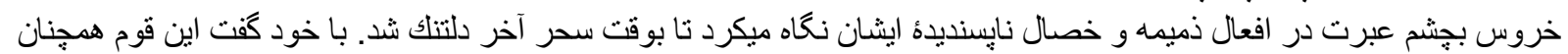

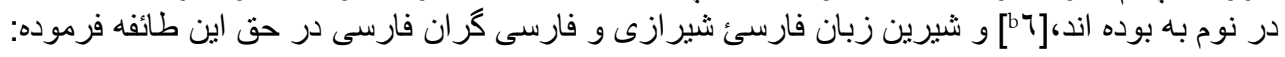

$$
\text { آنكه خو ابش بهتر از بيداريست }
$$

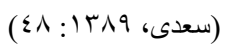

و و هابى در باب اينخواب كفته كه

$$
\text { باديدارئ ما كه غييتست و بهنان }
$$

با فكر دراز يا خيالات محال

بس بـشم من بسى بهتر ازان

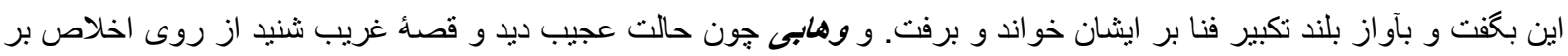

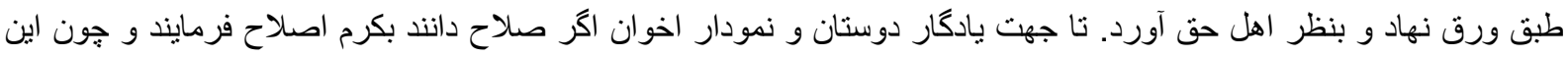

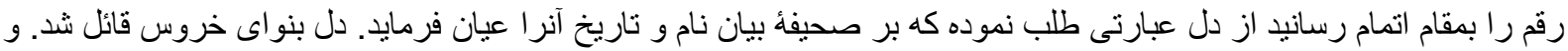

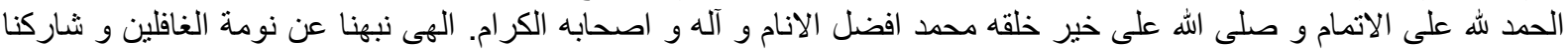

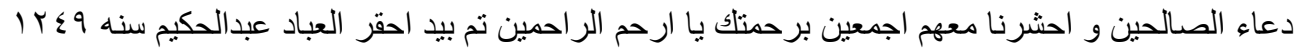




$$
\text { و كاتبها رميم في الخطى القرطاس دهر اب }
$$

\section{نتيجه كيرى}

خو اب يكى از اساسى ترين نياز هاى بدن انسان است. اهميت خواب هم در قر آن و هم در احاديث تأكيد شده است. اما خوابيدن به

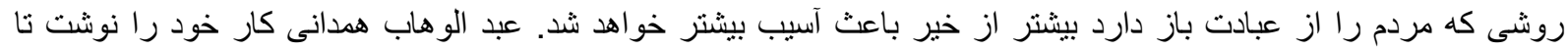

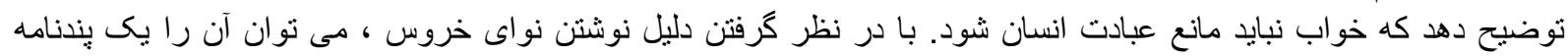

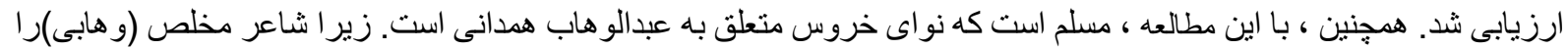

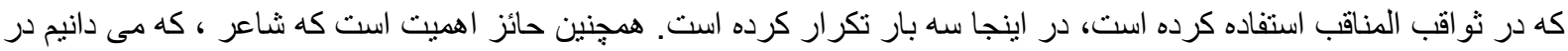

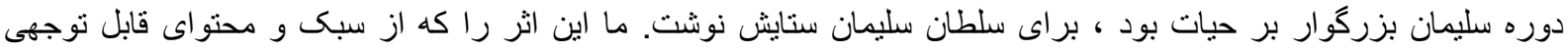

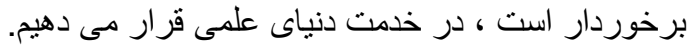

\section{فهرست منابع \\ ابو سعيد ابو الخير ، (بى تا) سخنان منظوم /بو سعبِ /بو الخبر؛ بـه اهتمام سعيد نفيسى، كتابخانهُ سنائى، جاب سوم.}

Buhârî, Ebû Abdillah Muhammed ibn İsmail el-Buhârî, (1987) el-Câmi'u's-Sahîh-Sahîh-i Buhârî ve

Tercemesi c. III, çev; Mehmed Sofuoğlu, Ötüken Yayınları.

بابا افضل كاثنانى، (بى تا) دبو ان حكبم افضل الدبن محمد مرقى كاشانى؛ بـه اهتمام مصطفى فيضى، حسن عاطفى، عباس

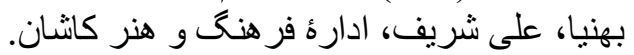

تقى الدين اوحدى بليانى، (ومب ا ) عرفات العاشقبن و عرصات العارفبن-جلد دوم؛ به اهتمام ذبيح الله صاحبكارى، آمنه

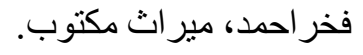

حافظ شير ازى مو لانا شمس الدين محمد، ( (q ب ا) ديولن غزليات ، به اهتمام خليل خطيب رهبر، انتشار ات صفى عليشاه،

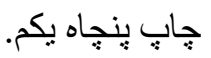

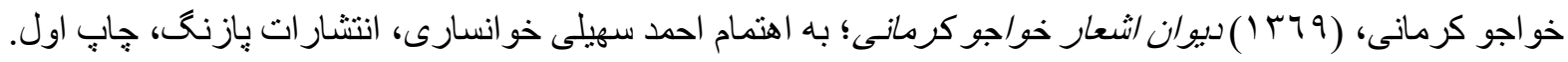
رشيدالدين وطو اط، (0 7 1 ) مطلوب كل طالب ؛ به اهتمام محمود عابدى، جإيخانهُ سلمان فارسى، جاب اول.

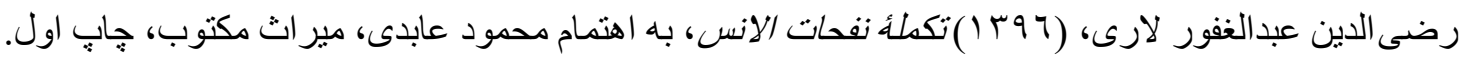
رودكى سمرقندى، (T T I ) دبيوان رودكى سمرقندى؛ به اهتمام سعيد نفيسى-ى. بر اكينسكى، مؤسسأ انتشار ات نكاه، جاֶٍ دوم.

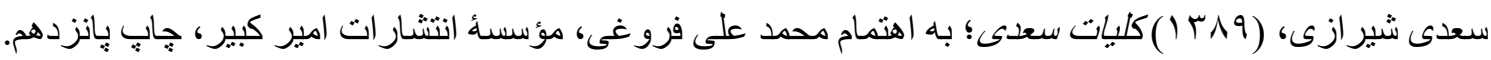

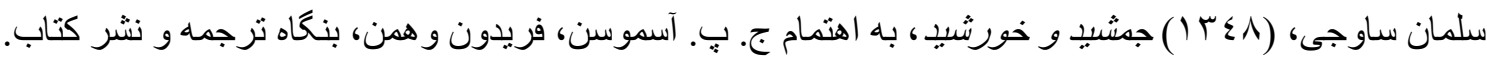

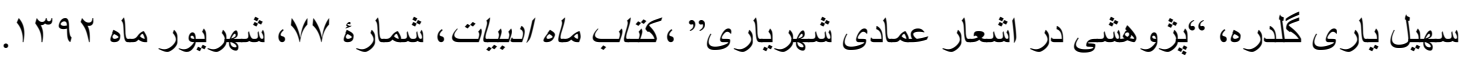
سيوطى، جلال الدين عبد الرحمن بن ابى بكر السيوطى، (بى تا) الجامع الصغبر ، بيروت، دار الفكر.

Soysaldı, H. Mehmet (2018). Kurân Âyetleri ve Hadisler Perspektifinden Uyku Hakkında Bir Değerlendirme. İ. Ü. İlahiyat Fakültesi Dergisi, Güz 2018/9 (2), 79-102.

$$
\begin{aligned}
& \text { عبدالو هاب بن جلال الدين محمد همدانى، ( • ب ( ) ثو اقب المناقب /وليا الله، به اهتمام عارف نوشاهى، مير اث مكتوب، } \\
& \text { جاب اول. }
\end{aligned}
$$

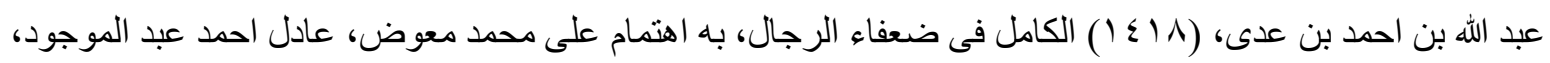
دار الكتب العلمية، الطبعة الاولى. 
Ali Alparslan, (1988) "Abdülvehhâb es-Sâbûnî”, Türkiye Diyanet Vakfi İslam Ansiklopedisi c.I, TDV Yayınları, İstanbul.

$$
\begin{aligned}
& \text { فردوسى طوسى، ( آT I ) منتخب شاهنامه ؛ به اهتمام محمد على فروغى، حبيب يغمائى، جايخانهُ سكه تجديد. }
\end{aligned}
$$

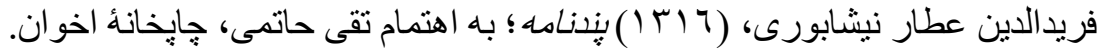

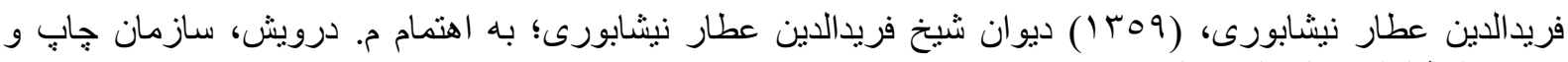

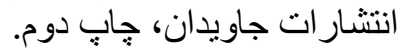

$$
\begin{aligned}
& \text { مسلم بن الحجاج القثشيرى النيسابورى، ( ع I IV ) صحيح مسلم؛ به اهتمام محمد فؤ اد عبد الباقى، دار احيا الكتب العربية، } \\
& \text { الطبعة الاولى. }
\end{aligned}
$$

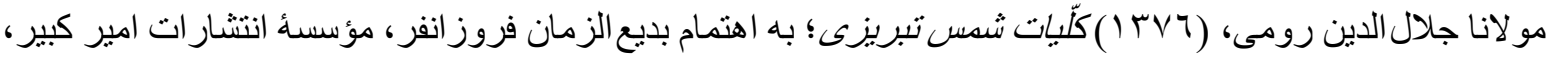

$$
\begin{aligned}
& \text { جاب جهاردمث. }
\end{aligned}
$$

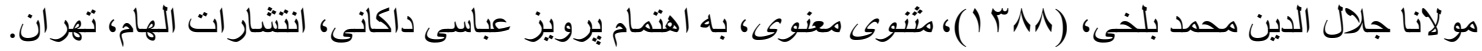

\section{Kaynakça}

Abdullah bin Ahmed bin Adiyy, (1418), el-Kâmil fí Zu'afâi’r-ricâl, Haz. Ali Muhammed Muavviz, Âdil Ahmed Abdülmevcûd, Dârü'l-kütübi'l-'ilmiyye.

Abdulvehhâb b. Celâleddîn Muhammed-i Hemedânî, (1390), Sevâkıbu'l-menâkıb-ı Evliyâillâh, Haz. Arif Nevşâhî, Tahran: Mîrâs-ı Mektûb.

Ali Alparslan, (1988) "Abdülvehhâb es-Sâbûnî”, Türkiye Diyanet Vakfi İslam Ansiklopedisi c.I, TDV Yayınları, İstanbul.

Baba Efdal-i Kâşânî, Dîvân-ı hakîm-i Efdalü'd-dîn Muhammed Merakî Kâşânî; be-ihtimâm-ı Mustafa Feyzî, Hasan Âtıfî, Abbâs Bihniyâ, Ali Şerîf, İdâre-i Ferheng ü Hüner-i Kâşân, Kâşân.

Buhârî, Ebû Abdillah Muhammed ibn İsmail el-Buhârî, (1987) el-Câmi'u's-Sahîh-Sahîh-i Buhârî ve Tercemesi c. III, çev; Mehmed Sofuoğlu, Ötüken Yayınları.

Ebû Sa'îd Ebû'l-hayr, Sühanân-ı Manzûm-ı Ebû Saî̀d Ebû'l-hayr; be-ihtimâm-ı Sa'îd Nefîsî, Kitâbhâne-i Senâ'î, çâp-ı süvvüm, Tahran.

Ferîdüddîn Attâr-1 Nişâbûrî, (1316) Pendnâme; Haz. Takî Hâtemî, Tahran: Çâphâne-i İhvân.

Ferîdüddîn Attâr-ı Nişâbûrî, (1359) Dîvân-ı Şeyh Ferîdüddîn-i Attâr-ı Nişâbûrî; Haz. M. Derviş, Tahran: Sâzmân-ı Çâp u İntişârât-ı Câvîân.

Firdevsî-i Tûsî, (1321) Müntahab-ı Şâhnâme; Haz. Muhammed Ali Fürûgî, Habîb Yağmâ̂̂̂, Tahran: Çâphâne-i Sikke-i Tecdîd.

Hâcû Kirmânî, (1369) Dîvân-ı Eş'âr-ı Hâcû Kirmânî; Haz. Ahmed Süheylî Hânsârî, Tahran: İntişârât-1 Pâzeng.

Hâfız-ı Şîrâzî Mevlânâ Şemseddîn Muhammed, (1391) Dîvân-ı Gazeliyyât; Haz. Halil Hatibrehber, Tahran: İntişârât-1 Safî̀ Alişâh.

Mevlânâ Celâleddîn-i Rûmî, (1376) Külliyât-ı Şems-i Tebrîzî; Haz. Bedîüzzamân Fürûzânfer, Tahran: Müessese-i İntişârât-ı Kebîr.

Mevlânâ Celâleddîn Muhammed-i Belhî, (1388) Mesnevî-i Ma'nevî; Haz. Pervîz Abbas-ı Dâkânî, Tahran: İntişârât-ı İlhâm.

Müslim el-Haccâc el-Kuşeyrî el-Nisâbûrî, (1374) Sahîh-i Müslim; Haz. Muhammed Fuâd Abdülbâkî, Dâru'l-ihyâ'i'l-kütübi'l-'arabiyye.

Radıyyüddîn Abdülgafûr-ı Lârî, (1396) Tekmile-i Nefehâtü’l-üns; Haz. Mahmûd Âbidî, Tahran: Mîrâs-ı Mektûb. 
Reşîüuddîn Vatvat, (1365) Matlûbu Külli Tâlib; Haz. Mahmûd Âbidî, Tahran: Çâphâne-i Selmân-1 Fârisî.

Rûdekî-i Semerkandî, (1376) Dîvân-ı Rûdek̂̂-i Semerkandî; Haz. Said Nefîsî, Y. Brankinski, Müessesei İntişârât-ı Nigâh.

Sa'dî-i Şîrâzî, (1389) Külliyât-ı Sa'dî; Haz. Muhammed Ali Fürûgî, Tahran: Müessese-i İntişârât-I Emîri Kebîr.

Selmân-ı Sâvecî, (1348) Cemşîd ü Hurşîd; Haz. C. P. Asmûsen, Ferîdûn Vehmen, Tahran: Büngâh-1 Terceme vü Neşr-i Kitâb.

Süheyl-i yarî Güldere, (1392) "Pijûhişî Der-eş’âr-ı İmâdî-i Şehriyârî", Kitâb-ı Mâh-ı Edebiyyât, No: 77, Tahran.

Süyûtî, Celâleddîn Abdurrahmân b. Ebî Bekr es-Süyûtî, (t.y.), el-Câmi’ü’s-sagîr, Beyrût: Dârül-fikr.

Soysaldı, H. Mehmet (2018). "Kurân Âyetleri ve Hadisler Perspektifinden Uyku Hakkında Bir Değerlendirme", I. Ü. İlahiyat Fakültesi Dergisi, Güz 2018/9 (2), 79-102.

Takıyyüddîn Evhadî-i Belyânî, (1389) Arafâtü’l-âş̧kîn ve Arasâtüll-ârifin -c. 2; be-ihtimâm-1 Zebîhullah Sâhibkârî, Âmine Fahrahmed, Mîrâs-ı Mektûb, Tahran. 